\title{
THE INFLUENCE OF COOPERATIVE LEARNING TEAM ASSISTED INDIVIDUALIZED (TAI) TYPE TO THE STUDENTS' LEARNING MOTIVATION AND ENGLISH READING COMPREHENSION AT STIK BINA HUSADA PALEMBANG
}

\author{
by \\ Agus Wahyudi \\ Email: wahyudiagus.aw@gmail.com
}

\begin{abstract}
As an international language, English plays an important role in making people acquire knowledge, information, skills in communication in order to compete with other people in the international level. For example, those who master English can easily communicate with people from other countries in English and can read scientific books written in English. In Indonesia, there is a great demand for the people to learn English both in formal education and in non-formal education. In order to take an active part or even to survive in the present state of technological advancements and rapid growth of the globalization, someone has to have proficient mastery of the English language. One way to develop students' achievement is through cooperative learning, they can work together, appreciate others' opinion and give others chance to share their opinion, therefore the students can have higher motivation because they are encouraged by others. The sample of this research is STIK Bina Husada students, the researcher gives treatment to the experimental group, that is Team Assisted Individualized (TAI), the results are compared between before and after the treatment, to analyze the motivation changes, the researcher distributes a quetionnaire through likert skale and t test, and to analyze students' reading comprehension, the researcher distributes a reading test. Based on statistical analysis, it is found that there is significant influence of cooperative learning to the students' learning motivaion and english reading comprehension where $t$ value in students motivaion 8.212 , reading comprehension 7.008 , in .000 significant level.
\end{abstract}

Keywords: TAI, learning motivation, reading achievement

\section{INTODUCTION}

As an international language, English plays an important role in making people acquire knowledge, information, skills in communication in order to compete with other people in the international level. For example, those who master English can easily communicate with people from other countries in English and can read scientific books written in English. In Indonesia, there is a great demand for the people to learn English both in formal education and in non-formal education.

In Indonesia, English is taught started from primary until university level, which involve four basic language skils, namely: listening, reading writing and speaking. Among the four skills, reading plays important role to someone's life and developes continually. Cheek, Filippo and Lindsey (1989:113) reading is a key factor in learning success, further Cooper (1988) states that reading is a process to develop the meaning in the printed and a cognitive process. 
One way to develop students reading comprehension is through cooperative learning, in order to create the effective instruction, at least 5 variables needed, they are: actively engage students, attract the interest and attention of students, motivate the students, pay attention to the ability of students and using appropriate props.

Motivation is the important thing in instruction process, therefore a teacher should be more creative in developing students' motivation and English reading comprehension in the classroom, it is needed also effective instructional technique.

Salah satu model pembelajaran efektif adalah pembelajaran kooperatif. Pembelajaran kooperatif dapat meningkatkan cara belajar siswa menuju belajar lebih baik, siswa dapat belajar secara berkelompok bersama teman-temannya dengan cara saling menghargai pendapat dan memberikan kesempatan kepada orang lain untuk menyampaikan pendapat mereka, sehingga siswa akan memiliki motivasi yang tinggi karena didorong dari temannya.

Cooperative learning is an approach to groupwork that minimizes the occurrence of those unpleasant situations and maximizes the learning and satisfaction that result from working on a highperformance team. A large and rapidly growing body of research confirms the effectiveness of cooperative learning in higher education. Relative to students taught traditionally-i.e., with instructor-centered lectures, individual assignments, and competitive grading - cooperatively taught students tend to exhibit higher academic achievement, greater persistence through graduation, better high-level reasoning and critical thinking skills, deeper understanding of learned material, greater time on task and less disruptive behaviour in class, lower levels of anxiety and stress, greater intrinsic motivation to learn and achieve, greater ability to view situations from others' perspectives, more positive and supportive relationships with peers, more positive attitudes toward subject areas, and higher self-esteem. Another nontrivial benefit for instructors is that when assignments are done cooperatively, the number of papers to grade decreases by a factor of three or four.

Based on the description above, the researcher would like to do a research entitled the influence of cooperative learning (team assisted individualized type) to the students' learning motivation and English reading comprehension at STIK Bina Husada Palembang

\section{RESEARCH METHODOLOGY}

This design of this research is pretest-posttest control group design, where the design can be drawn as follows:

$$
\begin{array}{lll}
\mathrm{O}_{1} & \times \mathrm{O}_{2} \\
\mathrm{O}_{3} & \times & \mathrm{O}_{4}
\end{array}
$$

The population and the sample of this research are the students of midwifery in STIK Bina Husada academic year 2013/2014 who was taking English 1 subject

\section{TECHNIQUE FOR COLLECTING THE DATA}

In order to collect the data of this research, questionnaire and test are distributed

Accoring to Singarimbun (1984:175) the goals of (a) to gain the relevan information in order to do a survei (b) to gain the highest validity and reliability information based on the definition above, the researher distibutes a questionnaire in order to measure students' learning motivation toward english

This questionnaire involves 40 questions adaped from Ethel Ogane \& Masako Sakamoto. The focus of this questionnaire involves:
a. Extrinsic motivation
b. Intrinsic motivation
c. Motivation strength
d. Hope
e. enxiety

Reading comprehension test is given to measure the students' understanding toward the reading. The test consists of 24 questions in the form of multiple choice questions and have been analyzed through Flesch Kincaid

\section{TECHNIQUE FOR ANALYZING THE DATA}

In order to fill the questionnaire, the respondent should consult to the indicator of each variable, where the indicators are strongly agree (SS), agree (S), neutral $(\mathrm{N})$, disagree (DS), strongly disagree (SD). In order to calculate whether the respondent possess high, medium or low motivation, each indicator will 
be analyzed how many items the respondent answer strongly agree (SS), agree $(\mathrm{S})$, neutral $(\mathrm{N})$, disagree (DS), strongly disagree (SD). For reading test, the researcher calculates how many number the respondent answer correct before and after the treatement.

\section{RESULT AND DISCUSSION}

English learning motivation before tretment

In this research, English learning motivation is devided into three categories; low, medium dan high. The result of analysis, it is found, 9 students in low, 29 in medium dan 16 students in high motivation.

\section{English learning motivation after the tretment}

After the treatment is given, there is a significant improvement in students' English learning motivation, in figure 1, it is found there is no more students in low motivation, 22 in medium, and 30 students in high motivation. Students' English learning motivation before and after the treatment can be seen in the following figure:

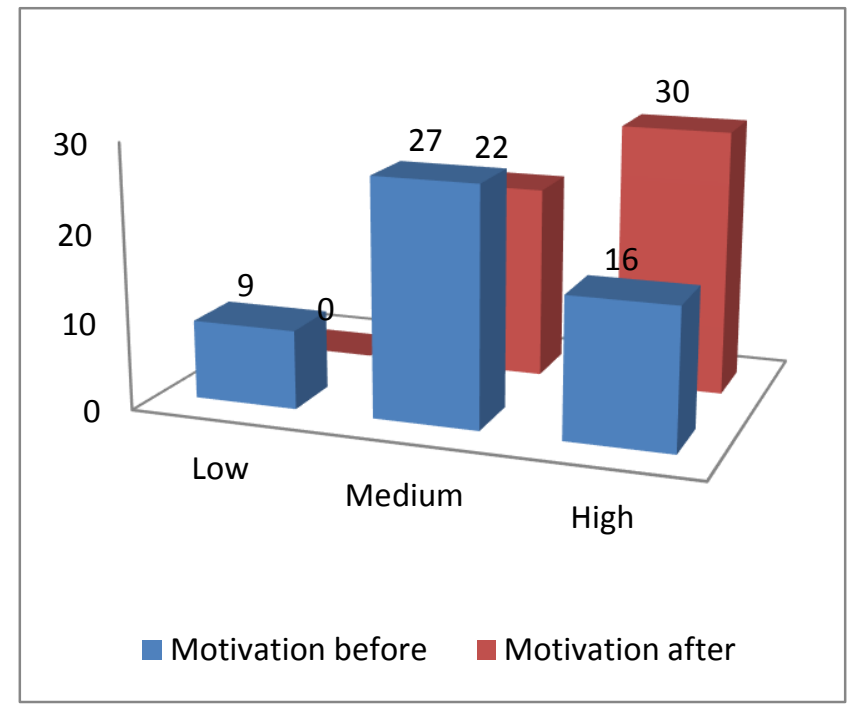

Figure 1. English learning motivation before and after the treatment

Students' reading comprehension before the treatment

In this research, students' English reading comprehension is divided into five categories: very low, low, average, good, excellent. Based on the result of the test it is found 4 students in very poor, 9 students in poor, 14 students in average, 24 students in good and 1 in excellent

$\begin{array}{ll}86-100 & \text { Excellent } \\ 71-85 & \text { Good } \\ 56-70 & \text { Average } \\ 41-55 & \text { Low } \\ \leq 40 & \text { Very Low } \\ \text { (Source: } & \text { FKIP/Universitas Sriwijaya) }\end{array}$

Students' reading comprehension after the treatment

After the treatment is given, there is no more student in very poor category, 9 students in average, 29 students in good and 14 students in excellent category. The result of students' reading comprehension before and after the treatment can be seen in the following figure:

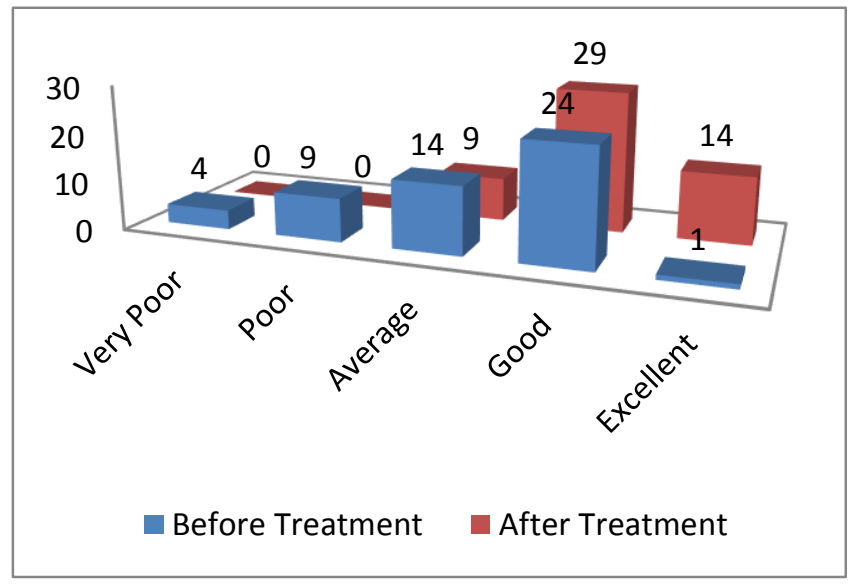

Figure 2: Students' reading comprehension before and after the treatment

The result of Paired Sample Test on Pre-test and Post-test of Motivation in English learning motivation

The result of statistic analysis of pretest and posttest can be seen in the following table

TABLE 1

PAIRED SAMPLE TEST OF STUDENTS' MOTIVATION

\begin{tabular}{|l|l|l|}
\hline & Pretest & Posttest \\
\hline
\end{tabular}




\begin{tabular}{|l|l|l|}
\hline Mean & 124.35 & 133.75 \\
\hline Std. Deviation & 15.256 & 12.774 \\
\hline Std. Error Mean & 2.116 & 1.771 \\
\hline $\mathrm{t}$ & 8.212 & \\
\hline $\mathrm{Sig}$ & .000 & \\
\hline
\end{tabular}

The table shows us the mean of the pretest is 124.35 , standard deviation is 15.256 , and std. error mean is 2.116 , while the mean of the post test is 133.75, standard deviation is 12.774 and standard error mean is $1.771, \mathrm{t}$ value 8.212 where the significant level is $.000<.05$. it can be concluded that there is a significant difference between before and after the treatment, or it can be said Team Assisted Individualized gives significant influence to the students' motivation

\section{Paired Sample Test Result Of Pretest And Posttest In Students Reading Comprehension}

TABLE 2

PAIRED SAMPLE TEST OF STUDENTS' READING COMPREHENSION

\begin{tabular}{|l|l|l|}
\hline & \multicolumn{1}{|c|}{ Pretest } & \multicolumn{1}{c|}{ Posttest } \\
\hline Mean & 66.54 & 79.87 \\
\hline Std. Deviation & 15.501 & 8.689 \\
\hline Std. Error Mean & 2.150 & 1.205 \\
\hline $\mathrm{t}$ & 7.008 \\
\hline Sig & .000 & \\
\hline
\end{tabular}

The table above tells us the mean of the pretest is 66.4, standard deviation is 15.501 and standard error mean is 2.150 , while the post test the mean of the posttest is 79.87 , standard deviation is 8.689 and the standard error mean is 1.205 , the $\mathrm{t}$-score is 7.008, where the significant level is $.000<.05$. it can be concluded that there is significant difference between before and after the treatment, further team assisted learning gives significant influence to the students' reading comprehension

\section{DISCUSSION}

The result of this research shows that the students who are taught by using team assisted individualized improve in term of English learning motivation and reading comprehension, the statistic result shows that $\mathrm{t}$ value in students English learning motivation is 8.212 and 7.008 in reading comprehension in .000 significant level, it can be stated that there is significant difference between before and after the treatment of the above variable.

\section{CONCLUSION AND SUGGESTION Conclusion}

The result of this study shows that there is a significant improvement in students' English learning motivation and reading comprehension achievement after they are given a treatment. Based on descriptive analysis, there is no more student in low motivation and low achievement in reading comprehension. It can be concluded that this type of cooperative learning has given benefits whether to the teacher itself or the group of the students. They complete the academi tasks together, for example:

1) The students who are good in academic performance have responsible to help the students who are not to develop their ability and skills

2) The students who are weak in academic performance will acquire the academic materials easier

3) There is no competition among students because they work together to overcome the problems

4) The students do not count on to teacher's help, but they are motivated to study all the materials,

5) the researcher uses his half of the teaching time, so he can help the students individually

\section{B. Suggestion}

After doing this research, the researcher suggests the parents, lecturers or teachers, other researchers and government to

1. Being good in English does not happen in one time, there should be a continuous process, it is hoped the parents can facilitate their children with books, English materials at home. It is hoped that they can have good motivation and attitude toward English

2. It is hoped the lecturers or teachers to use variation in technique in teaching English. 
3. To other researchers, it is hoped that they can do a research that has something to do with this discussion further

\section{REFERENCES}

Arikunto, S. (1996). Prosedur penelitian. Jakarta:

BumiAksara

Gardner, R. C., \& Lambert W. E. (1972). Attitudes and motivation in second language learning. Rowley, MA: Newbury House.

Gardner, R. C. (1985).The social psychology and second language learning: The role of attitudes and motivation. London: Edward Arnold, Ltd.

Gardner, R. C. (2006). Motivation and second language acquisition: The socio-educational model. New York, NY: Peter Lang Publishing.

Narayanan, R.A. (2008). Some factors affecting English learning at tertiary level. Iranian Journal of Language Studies (IJLS), 2(4), 485512.

Retrieved

from

http://www.ijls.net/volumes/volume2issue4/nar ayan1.pdf

OECD. (2009). Indonesia Reading Proficiency and Influencing Factors. Retrieved from http://www.google.co.id/\#hl=id\&gs $n f=3 \& p q=$ reading\%20achievement\%20in\%20indonesia\% 20(pisa)\&cp=29\&gs_id=ei\&xhr=t\&q=Informat ion\%20about\%20Indonesian\%20Reading\%20A chievement $\% 20$ (Pisa) \&pf=p\&sclient $=$ psyab\&oq=Information+about+Indonesian+Readin $\mathrm{g}+$ Achievement $+($ Pisa $) \& g s \quad l=\& p b x=1 \& b a v=0$ n.2,or.r_gc.r_pw.r_qf.\&fp=df9dd13ba491c8d8 $\& \mathrm{bpcl}=35277026 \& b i w=1024 \& b i h=499$. On $15^{\text {th }}$ of October 2012

OECD (2010) PISA 2009 Results: Executive Summary. Retrieved from www.oecd.org/publishing.corrigenda on March 3rd, 2012.

Readability index calculator. (2012). Methods for measuring text readability. (online). http://www.standardsschmandards.com/exhibits/rix/index.php. Retrieved on October 19th, 2012

Wahyudi, A. (2012). The Correlation among English Learning Motivation, Attiude and English Proficiency of Students of Five D3 Nursing Science School in Palembang. Unpublished Graduate Thesis, Graduate School Sriwijaya University, Palembang. 